\title{
PENGARUH KEPEMIMPINAN TRANSFORMASIONAL DAN MOTIVASI TERHADAP KINERJA PENGERAJIN GERABAH DI KELURAHAN BANYUNING
}

\author{
L.D. Devayanti ${ }^{1}$, G.P.A.J. Susila ${ }^{2}$ \\ 1,2 Jurusan Manajemen, Universitas Pendidikan Ganesha, Singaraja \\ e-mail: devidevayanti19@undiksha.ac.id ${ }^{1}$, agus.jana@undiksha.ac.id²
}

\begin{abstract}
Abstrak
Tujuan penelitian ini adalah untuk menguji (1) kepemimpinan transformasional dan motivasi terhadap kinerja (2) kepemimpinan transformasional terhadap kinerja (3) motivasi terhadap kinerja. Subjek dari penelitian ini adalah pengerajin gerabah di Kelurahan Banyuning. Objek penelitian yang digunakan yaitu kepemimpinan transformasional, motivasi, dan kinerja. Populasi yang digunakan dalam penelitian ini berjumlah 35 orang pengerajin gerabah di Kelurahan Banyuning. Metode kuantitatif digunakan dalam penelitian ini. Teknik pengumpulan data yang digunakan dalam penelitian ini adalah pencatatan dokumen, dan kuesioner selanjutnya dianalisis dengan menggunakan analisis regresi linier berganda. Hasil penelitian ini menunjukkan bahwa (1) kepemimpinan transformasional dan motivasi berpengaruh positif dan signifikan terhadap kinerja (2) kepemimpinan transformasional berpengaruh positif dan signifikan terhadap kinerja (3) motivasi berpengaruh positif dan signifikan terhadap kinerja.
\end{abstract}

Kata Kunci: kepemimpinan transformasional, motivasi, kinerja.

\begin{abstract}
This study aims to examine the effect of (1) transformational leadership and motivation on performance (2) transformational leadership on performance (3) motivation on performance. The subjects of this study were earthenware's craftsman at Banyuning Village. While the object of this research is, transformational leadership, motivation and performance. The population used in this study was 35 pottery craftsman at Banyuning Village. Quantitative methods used for this research. Data collection techniques in this study were using a document recording, questionnaire, then the data were analyzed using with multiple linear regression test. The results showed that (1) transformational leadership and motivation had a positive and significant effect on performance (2) transformational leadership had a positive and significant effect on performance (3) motivation had a positive and significant effect on performance.
\end{abstract}

Keywords: transformational leadership, motivation, performance

\section{Pendahuluan}

Dalam era globalisasi saat ini, lingkungan organisasi berubah secara kompleks dan tingginya daya saing, dimana perusahaan diharuskan untuk lebih peka akan keadaan agar tetap bertahan. Pemimpin sebagai individu panutan dalam organisasi akan tidak mudah melalui perubahan ini dan harus melewatinya dengan proses. Dalam suatu perusahaan maupun organisasi, harus diawali dengan perubahan mulai dari tingkat paling atas yaitu atasan atau pemimpin. perusahaan membutuhkan pemimpin yang bersifat ideal dan bergaya reformasi yang mampu menggerakkan perubahan (transformation) dalam perusahaan. Dimasa mendatang kemajuan pembangunan sumber daya manusia dimana sumber daya manusia itu sendiri harus dianggap subjek dalam pembagunan bukan dianggap objek pembangunan lagi. Seperti yang dikutip dari kemeperin.go.id, Kementerian Perindustrian (Kemenperin) ingin mendorong dan membuat industri kecil yang mandiri dan memiliki daya saing yang tinggi. Pemerintah dalam hal ini memberikan perhatian pada industri kecil tersebut agar tercipta industry kecil yang terampil terutama pada sumber daya manusianya.

Industri kecil yang ada di Singaraja terdiri dari berbagai sektor. Mulai dari sektor perdagangan, jasa, maupun produksi. Salah satunya yaitu Gerabah di Kelurahan Banyuning, Kecamatan Buleleng, Kabupaten Buleleng. Gerabah Kelurahan Banyuning 
merupakan usaha menengah yang bergerak pada bidang produksi kerajinan yang terbuat dari tanah liat seperti pot, priuk, cubek, payuk kedas, caratan, souvernir, dan berbagai kerajinan lainnya. Gerabah Banyuning telah lama menjadi ikon kerajinan di Kota Singaraja. Usaha gerabah Banyuning menggunakan metode tradisional dalam pembuatan berbagai kerajinan gerabahnya.

Gerabah Kelurahan Banyuning merupakan usaha menengah yang bergerak pada bidang produksi kerajinan yang terbuat dari tanah liat seperti pot, priuk, cubek, payuk kedas, caratan, souvernir, dan berbagai kerajinan lainnya. Gerabah Banyuning telah lama menjadi ikon kerajinan di Kota Singaraja. Usaha gerabah Banyuning menggunakan metode tradisional dalam pembuatan berbagai kerajinan gerabahnya. Usaha Gerabah Banyuning terdiri dari beberapa divisi. Pertama yaitu divisi bahan baku yang bertugas untuk menyiapkan bahan baku seperti tanah liat. Kedua yaitu divisi pengolahan yang bertugas untuk melakukan proses pengolahan tanah liat menjadi gerabah meliputi proses pencetakan, pengeringan, pembakaran, dan finishing. Ketiga yaitu divisi pemasaran yang bertugas untuk memasarkan produk meliputi menjaga kios-kios penjualan gerabah dan pendistribusian gerabah.

Proses pembuatan gerabah diawali oleh proses penyiapan bahan baku. Bahan baku gerabah merupakan campuran dua jenis tanah yaitu tanah liat yang bertekstur lentur dan sulit menyerap air dengan tanah yang tidak bening, berpori dan menyerap air dicampur sesuai dengan takaran. Kemudian, tanah campuran tersebut dicetak dengan teknik cetak tekan dan untuk produk lainnya seperti batu bata dan genteng di press dengan mesin yang masih trandisonal. Setelah terbentuk, gerabah dikeringkan dengan dijemur dibawah sinar matahari dan dibakar selama lima jam dengan tungku bakar tradisional yang dibakar menggunakan kayu bakar. Setelah dibakar produk gerabah sudah siap dipasarkan, dan untuk produk souvernir maupun hiasan harus melalui tahap pengecatan untuk menambah estetika produk.

Observasi yang telah dilakukan mendapatkan informasi bahwa pada bulan Juli ke Agustus terjadi penurunan produktivitas gerabah di Kelurahan Banyuning sebesar $8 \%$ dan pada bulan Agustus ke September terjadi penurunan 6\%. Penurunan produktivitas dilihat dari jumlah produksi yang tidak mencapai target. Hal tersebut terjadi diakibatkan kinerja pengerajin gerabah yang rendah. Muchdarsyah (2003:16) menyatakan bahwa kinerja atau hasil kerja dapat diukur dengan melihat produktifitas

Sehingga penurunan produktivitas gerabah di Kelurahan Banyuning diduga terjadi karena kinerja pengerajinnya rendah. Untuk mencapai tingkat produktifitas yang tinggi maka harus meningkatkan kinerja pengerajin terlebih dahulu.

Kemudian, dilakukan kembali penyebaran kuisioner awal dan diketahui yang mempengaruhi kinerja ada banyak factor seperti kepemimpinan transformasional dan motivasi. Produktifitas usaha gerabah di Kelurahan Banyuning mengalami penurunan pada bulan Juli sampai dengan Agustus 2020. Sehingga penurunan produktivitas gerabah di Kelurahan Banyuning diduga terjadi karena kinerja pengerajinnya rendah. Diperkuat dengan teori Sedarmayanti (2010:188) dimana dikatakan bahwa kinerja yang meningkat dikarenakan kepemimpinan transformasional dapat meningkatkan motivasi yang berkaitan dengan motivasi sebagai peningkat kinerja pengikutnya.

Penerapan kepemimpinan transformasional dilihat pada tanggung jawab karyawannya. Tanggung jawab adalah seberapa mampu karyawan untuk menyelesaikan tugas tepat waktu dan penuh tanggung jawab. Dalam bekerja, pengerajin gerabah sering kali tidak bertanggungjawab terhadap pekerjaannya karena sering tidak menyelesaikan pekerjaan dengan tepat waktu. Hal ini juga dikarenakan pengerajin sering mengulur waktu bekerja sehingga saat jam kerja selesai pekerjaan mereka belum terselesaikan karena pemimpin memberikan perintah secara tidak baik dan kurang sopan dalam penyampaiannya. Karyawan merasa kurang diakui dan tidak diperhatikan keberadaannya di tempat bekerja, karena tidak dilibatkan dalam pemecahan masalah dan pencarian solusi. Kemudian dikuatkan oleh teori yang dikemukakan oleh Munawaroh (2011) menyatakan bahwa gaya kepemimpinan transformasional membangkitkan motivasi pegawai dalam mencapai kinerja yang lebih dari apa yang diharapkan sebelumnya. 
Rendahnya motivasi juga dapat dilihat pada Atasan memberikan perintah dengan cara dan bahasa yang cenderung frontal dan kurang sopan dan atasan tidak mampu memotivasi karyawan dengan baik sehingga dapat mempengaruhi peningkatan kinerja karyawan. Atasan harus mampu mempengaruhi karyawan dengan memotivasi dengan cara yang baik sehingga karyawan akan semangat mengerjakan tugas yang diberikan kepadanya. Jika pemimpin sudah mampu memotivasi bawahannya maka akan memunculkan timbal balik berupa kinerja yang maksimal dari karyawannya begitu pula sebaliknya.

Rendahnya kinerja dikarenakan tempat produksi dan pemasaran gerabah berada di tempat yang berbeda. Karyawan merasa tidak diperhatikan oleh atasan. Tidak ada hubungan yang baik terjalin antara atasan dengan bawahannya. Karyawan merasa kurang adanya dukungan dan dorongan dalam bekerja. sehingga, masalah-masalah yang timbul saat bekerja tidak bisa dicarikan solusi bersama oleh pemimpin dengan karyawan. Hal tersebut menyebabkan karyawan tidak termotivasi dan kurang semangat sehingga menurunkan kinerja. Oleh karena itu, kepemimpinan transformasional dan motivasi dapat mempengaruhi kinerja pengerajin gerabah di kelurahan Banyuning yang ditegaskan oleh teori yang dikemukakan oleh Griffin (2003) bahwa faktor yang sangat mampu menentukan sebuah kinerja adalah motivasi.

Definisi Kepemimpinan transformasional menurut Bass dalam Yukl (2009:305) merupakan pengaruh pimpinan kepada bawahan atau pengikut. Kesetiaan kepercayaan, penghormatan serta kekaguman dapat dirasakan pengikut terhadap pemimpin, dan termotivasi untuk melakukan lebihsebelumnya. Karyawan harus mampu menimbulkan motivasi dari luar maupun dalam diri untuk mencapai kinerja. Sunyoto (2012:11) menyatakan motivasi adalah hal yang mendorong yang timbul dari diri sendiri. Baik dari luar maupun dalam diri agar bersemangat dalam bekerja dengan tujuan mencapai target perusahaan dengan menggunakan semua keterampilan serta kemampuan yang dimiliki. Dimana definisi kinerja menurut Rivai (2005:14) adalah keseluruhan hasil kesuksesan seseorang dalam periode tertentu berupa kinerja, sasaran atau target yang sebelumnya disepakati bersama.

Sedarmayanti (2010:188) dimana dikatakan bahwa kinerja yang meningkat dikarenakan kepemimpinan transformasional dapat meningkatkan motivasi yang berkaitan dengan motivasi sebagai peningkat kinerja pengikutnya. Adapun indikator kinerja adalah kualitas, kuantitas, pelaksanaan tugas, tanggung jawab. Didukung oleh penelitian Suryani dan Pramandari (2015) yang menunjukkan hasil bahwa kepemimpinan tranformasional dan motivasi berpengaruh positif terhadap kinerja. Berdasarkan hal tersebut diatas maka mendapat hipotesis yaitu: $\mathrm{H}_{1}$ : Ada pengaruh kepemimpinan transformasional dan motivasi terhadap kinerja pengerajin gerabah di Kelurahan Banyuning.

Munawaroh (2011) menyatakan bahwa gaya kepemimpinan transformasional membangkitkan motivasi pegawai dalam mencapai kinerja yang lebih dari apa yang diharapkan sebelumnya. Indikator yang digunakan pada variabel kepemimpinan transformasional adalah pengaruh ideal motivasi, inspirasional, stimulasi intelektual, pertimbangan. Didukung oleh penelitian yang Yuliaarnita (2013) yang menyatakan bahwa kepemimpinan transformasional secara parsial memiliki pengaruh yang positif dan signifikan terhadap kinerja. Sehingga, dapat disusun hipotesis yaitu: $\mathrm{H}_{2}$ : Ada pengaruh kepemimpinan transformasional terhadap kinerja pengerajin gerabah di Kelurahan Banyuning.

Motivasi merupakan faktor yang mempengaruhi kinerja (Mangkunegara, 2010). Adapun indikator motivasi adalah kebutuhan fisik, kebutuhan rasa aman dan keselamatan, kebutuhan sosial, kebutuhan penghargaan diri dan pengakuan, kebutuhan perwujudan diri. termotivasinya karyawan akan meningkatkan timbulnya kinerja yang dicapai. Didukung dengan penelitian Nur dan Sjahruddin (2019) yang didapat hasil bahwa motivasi secara parsial memiliki pengaruh yang positif dan signifikan terhadap kinerja. Hipotesis yang dapat dirumuskan yaitu: H3: Ada pengaruh motivasi terhadap kinerja pengerajin gerabah di Kelurahan Banyuning.

Kinerja yang kurang optimal diakibatkan oleh penerapan kepemimpinan transformasional yang masih rendah ditandai dengan pemimpin yang kurang berhubungan baik dengan karyawannya.. Pemimpin hanya memberikan perintah kepada bawahan. Pemimpin kurang bisa menginformasikan perintah kepada bawahan dengan baik sehingga 
penerapan kepemimpinan transformasional dinilai masih rendah. Pemimpin harus mampu menjadi teladan bagi bawahan dan mampu berbaur bersama karyawan sebab dengan itu karyawan merasa dihargai keberadaannya pada perusahaan. Sehingga, kepemimpinan transformasional besar pengaruhnya dalam mencapai kinerja. Didorong oleh teori yang dikemukakan oleh O'Leary (2001:21) yang menyatakan bahwa kinerja dapat ditingkatkan dengan kepemimpinan transformasional jika diperlukan.

Faktor motivasi memiliki pengaruh pada rendahnya kinerja. Pengerajin gerabah di Kelurahan banyuning merasa kurang motivasi dalam bekerja dilihat dari pengerajin yang merasa tidak ada pemberian dukungan baik dari pemimpin maupun rekan kerja. Mereka merasa hanya diberikan perintah tanpa ada dorongan semangat. Pemimpin tidak mengajak karyawan dalam pemecahan persoalan perusahaan sehingga karyawan merasakan bahwa dirinya tidak diakui keberadaanya pada perusahaan tersebut sehingga karyawan kerap kali tidak menyelesaikan pekerjaan dengan tepat waktu. Hal ini didukung dengan teori yang Griffin (2003) bahwa faktor yang sangat mampu menentukan sebuah kinerja adalah motivasi.

Rumusan masalah yang dapat disusun adalah (1) Apakah ada pengaruh kepemimpinan transformasional dan motivasi terhadap kinerja pengerajin gerabah di Kelurahan Banyuning?. (2) Apakah ada pengaruh kepemimpinan transformasional terhadap kinerja pengerajin gerabah di Kelurahan Banyuning? (3) Apakah ada pengaruh motivasi terhadap kinerja pengerajin gerabah di Kelurahan Banyuning?. Tujuan yang ingin dicapai yaitu (1) Kepemimpinan transformasional dan motivasi terhadap kinerja pengerajin gerabah di Kelurahan Banyuning (2) Kepemimpinan transformasional terhadap kinerja pengerajin gerabah di Kelurahan Banyuning (3) Motivasi terhadap kinerja pengerajin gerabah di Kelurahan Banyuning.

Hasil penelitian ini diharapkan (1) Secara Teoritis. Hasil penelitian ini diharapkan dapat menambah ilmu dalam bidang ekonomi manajemen sumber daya manusia dan digunakan untuk menambah wawasan dan melatih dalam berpikir dengan berdasarkan disiplin ilmu sumber daya manusia. (2) Secara Praktis. Manfaat yang diharapkan terutama bagi usaha UMKM (Usaha Mikro Kecil dan Menengah) Gerabah Banyuning dan para pengerajin Gerabah di Kelurahan Banyuning untuk meningkatkan kinerja dan agar mengetahui besaran dampak kepemimpinan transformasional dan motivasi sehingga menjadi pedoman mencari solusi di masa depan. Bertitik tolak pada latar belakang penelitian diatas, maka penelitian ini mengangkat judul "Pengaruh Kepemimpinan Transformasional dan Motivasi terhadap Kinerja Pengerajin Gerabah di Kelurahan Banyuning.

\section{Metode}

Mendapatkan informasi terkait pengaruh kepemimpinan transformasional dan motivasi terhadap kinerja pengerajin gerabah di Kelurahan Banyuning merupakan tujuan dari penelitian ini. Terdapat tiga variabel yang diteliti, yaitu kepemimpinan transformasional $\left(X_{1}\right)$ dan motivasi $\left(\mathrm{X}_{2}\right)$ sebagai variabel bebas (independent) dan kinerja $(\mathrm{Y})$ sebagai variabel terikat (dependent). Berdasarkan karakteristik masalah yang di teliti maka desain penelitian kuantitatif klausal dipilih agar mampu membuktikan hubungan sebab-akibat dan analisis pengaruh variabel satu dengan lainnya (Umar,2004). Penelitian kuantitatif kausal terdiri dari (1) merumuskan masalah, (2) mengkaji teori, (3) merumuskan hipotesis, (4) mengumpulkan data, (5) mengolah data, dan (6) menarik kesimpulan. Yang digunakan pada metode pengumpulan data adalah observasi, kuesioner dan pencatatan dokumen. Analisis regresi linear berganda digunakan sebagai metode penelitian.

Menurut Sugiyono (2009) Populasi merupakan wilayah yang secara umum berisi objek maupun subjek yang berkarakteristik tertentu yang ditetapkan, dipelajari dan cari kesimpulannya.

Populasi yang digunakan yaitu pengerajin gerabah di Kelurahan Banyuning sebanyak 35 orang. Penelitian ini dikategorikan sebagai populasi karena menurut Arikunto (2006) dikatakan penelitian populasi jika subyek berjumlah kurang dari 100 dan diambil keselurahan populasi tersebut. Jenis data kuantitatif merupakan jenis data dipakai dalam penelitian ini. Data yang digunakan berupa data hasil kuesioner. Terdapat dua jenis data berdasarkan 
sumbernya yang biasa digunakan dalam penelitian yaitu data primer serta data sekunder. Data yang dirangkum dari jawaban responden terhadap item pernyataan yang ada pada kuisioner disebut data primer. Sedangkan data sekunder adalah data yang berupa arsip atau dokumen dari suatu perusahaan.

Pengumpulan data dilakukan dengan: (1) Kuesioner, menurut Arikunto (2006), kuisioner adalah pertanyaan yang ditulis untuk mendapatkan suatu informasi mengenai sesuatu yang ingin diketahui peneliti kepada respondennya. Kuesioner tertutup digunakan dimana sudah disediakan jawaban dan responden tinggal memilihnya. Dalam penelitian ini penyebaran kuesioner adalah data mengenai tanggapan karyawan terhadap pernyataan terkait dengan kepemimpinan transformasional, motivasi dan kinerja pengerajin gerabah Banyuning. (2) Pencatatan dokumen merupakan salah satu cara pengumpulan data melalui pencatatan arsip-arsip atau dokumen-dokumen yang dimiliki oleh perusahaan. Data-data tersebut dimiliki dan diperoleh dari pemilik perusahaan. Data-data atau arsip-arsip perusahaan tersebut adalah seperti data jumlah serta nama-nama karyawan, jumlah karyawan berdasarkan jenis kelamin dan umur, dan pembagian karyawan berdasarkan jenis pekerjaannya.

Instrumen penelitian ini adalah kuisioner untuk mengukur mengukur besar kecilnya suatu variabel. Di dalam kuisioner berisi beberapa butir pernyataan yang akan ditanggapi oleh responden. Skala Likert digunakan dalam mendapatkan skor kuesioner. Menurut Sugiyono (2009) bahwa skala Likert digunakan terkait mengukur fenomena sosial yaitu mengukur suatu pendapat, mengukur sikap seseorang, serta cara pandang orang maupun beberapa orang. Dalam kuisioner ini berisi butiran pernyataan mengenai kepemimpinan transformasional, motivasi dan kinerja.

Pada penelitian ini menggunakan metode analisis kuantitatif. Data penelitian dianalisis menggunakan rumus-rumus statistik dengan analisis regresi berganda dimana data diolah memakai program SPPS for Windows versi 25. Teknik analisis data menggunakan analisis regresi linier berganda karena berdasarkan paradigma yang diduga tidak ada keterkaitan atau korelasi antar variabel bebas. Analisis regresi linear berganda ini digunakan untuk mengetahui besaran pengaruh antara kepemimpinan transformasional dan motivasi terhadap kinerja.

Sebelum dilakukan analisis regresi linier berganda, terlebih dahulu yang harus dilakukan adalah uji asumsi klasik terdiri dari (1) uji normalitas. Uji normalitas menurut Ghozali (2009) untuk menguji model regresi apakah variabel residual (pengganggu) berdistribusi normal atau tidak. Dimana yang baik jika uji t dan uji F menjelaskan bahwa nilai residual mengikuti distribusi normal. Data dikatakan memenuhi asumsi normalitas uji normalitas saat data pada grafik p-plot menyebar pada sekitar garis diagonal dan data mengikuti arah garis di diagonal tersebut. Jika tidak mengikuti arah grafik histogram maka dapat dikatakan tidak memenuhi asumsi normalitas.Uji Kolmogorov-Smirnov juga dilakukan untuk menguji normalitas yaitu dengan melihat nilai Asymp.sig (2-tailed) yang harus lebih besar dari pada 0,05 atau 5\%. Maka hal tersebut diartikan data berdistribusi normal (Ghozali, 2009). (2) Uji multikolinearitas, bertujuan agar menemukan ada atau tidaknya hubungan antara variabel bebasnya. Jika tidak ada hubungan antar variabelnya model regersi dapat diartikan sebagai model regresi yang kurang baik. Variabel-variabel tidak ortogonal jika ada korelasi antar variabel (Ghozali, 2009). Data dapat dikatakan tidak terjadi gejala multikoliniearitas, jika nilai tolerance value $>10 \%$ atau 0,1 dan nilai VIF $<10$. (3) Uji Heterokedastisitas. Saat model tidak mengalami kesamaan varian residual antara satu data dengan lainnya maka disebut heterokedastisitas. Jika sama satu dengan yang lainnya maka disebut dengan homokedastisitas (Ghozali, 2009). Grafik scatterplot digunakan untuk mengetahui ada tidaknya gejala heterokedastisitas pada model regresi. Jika membentuk pola yang teratur seperti melebar menyempit atau berhelombang maka dikatakan telah terjadi heterokedastisitas. Sedangkan jika titik menyabar diatas dan dibawah angka nol di sumbu Y, maka diartikan heterokedastisitas tidak terjadi. Menganalisis menggunakan Grafik plot ada kekurangannya jika jumlah data yang diinput sedikit maka akan makin sulit mengartikan informasi yang dihasilkan dari grafik plot karena mempengaruhi hasil ploting. Dengan uji Glejser lebih mampu menjamin keakuratan yang dapat dilihat dari probabilitas 
signifikansinya diatas 5\%. Maka dapat dikatakan model regresi yang diuji tidak mengalami gejala heterokedastisitas.

\section{Hasil dan Pembahasan}

Analisis regresi berganda digunakan sebab sangat kompleks data-data yang digunakan yang mengharuskan menggunakan analisis regresi berganda bukan analisis linear sederhana. Variabel yang lebih dari satu yaitu dia variabel independent atau bebas dan satu variabel dependent atau terikat juga menjadi alasan untuk menggunakan analisis regresi linear berganda. Pengolahan data dilakukan program Statistical Package for Social Science (SPSS), yang dilakukan guna mendapatkan informasi terkait pengaruh yang terjadi pada variabel independent kepemimpinan transformasional dan motivasi terhadap variabel dependent yaitu kinerja terkait ada atau tidakadanya pengaruh antar variabel tersebut.

Setelah diuji maka dapat disajikan dalam tabel berikut yaitu ringkasan hasil output SPSS yang dapat dilihat pada Tabel 1.

Tabel 1

Ringkasan Hasil Analisis Regresi Linier Berganda

\begin{tabular}{lcccc}
\hline \multicolumn{1}{c}{ Variabel } & Koefisien & T & F & Sig. \\
\hline Regression & & & 62,897 & \\
Konstanta & 2,087 & 2,205 & & 0.035 \\
Kepemimpinan & 0,447 & 2,951 & & 0.006 \\
Transformasional & 0,386 & 2,997 & & 0.005 \\
Motivasi & & & \\
\hline
\end{tabular}

Struktur hubungan pengaruh Kepemimpinan Transformasional $\left(X_{1}\right)$ dan Motivasi $\left(X_{2}\right)$ terhadap Kinerja (Y) yaitu dapat dilihat pada Gambar 1 berikut.
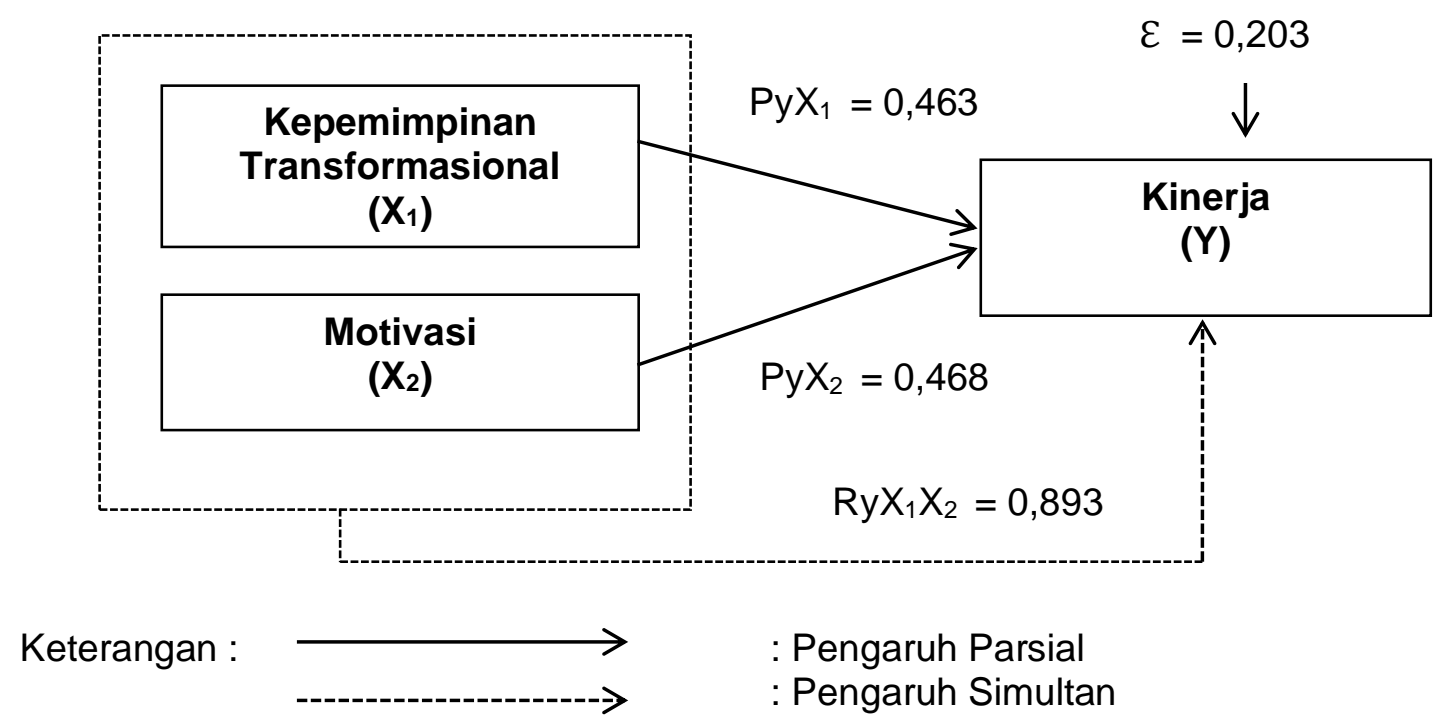

Gambar 1

Struktur Hubungan Pengaruh Kepemimpinan Transformasional dan Motivasi terhadap Kinerja Pengerajin Gerabah di Kelurahan Banyuning

Pada Tabel 1 diperoleh hasil nilai konstanta $(\alpha)$ sebesar 2,087. Nilai koefisien regresi Kepemimpinan Transformasional $\left(\beta_{1}\right)$ sebesar 0,447 dan nilai koefisien regresi Motivasi $\left(\beta_{2}\right)$ sebesar 0,386 . Sehingga persamaan regresi diformulasikan sebagai berikut:

$$
Y=2,087+0,447 X_{1}+0,386 X_{2}+0,203 \varepsilon
$$


Dari persamaan linier berganda tersebut menunjukkan bahwa: (1) Konstanta sebesar 2,087, artinya bahwa apabila Kepemimpinan Transformasional $\left(\mathrm{X}_{1}\right)$ dan Motivasi $\left(\mathrm{X}_{2}\right)$, nilainya sama dengan nol, maka Kinerja $(Y)$ sebesar 2,087. (2) Nilai koefisien Kepemimpinan Transformasional $\left(\beta_{1}\right)$ senilai 0,447 berarti bahwa Kepemimpinan Transformasional memiliki pengaruh positif terhadap Kinerja $(Y)$. Hal ini mengartikan bahwa setiap kenaikan Kepemimpinan Transformasional satu satuan maka variabel Kinerja meningkat sebesar 0,447 sehingga menjadi 2,534 $(2,087+0,447)$, dengan asumsi bahwa variabel bebas yang lainnya tidak berubah (3) Nilai koefisien Motivasi $\left(\beta_{2}\right)$ sebesar 0,386 berarti bahwa Motivasi memiliki pengaruh positif terhadap Kinerja $(Y)$. Hal ini mengartikan bahwa setiap kenaikan Motivasi satu satuan maka variabel Kinerja meningkat senilai 0,386 sehingga menjadi 2,473 $(2,087+0,386)$, mengasumsikan bahwa variabel bebas yang lainnya tidak berubah.

Koefisien determinasi $\left(R^{2}\right)$ menurut Ghozali (2009) digunakan untuk mencari seberapa mampu model dalam menggambarkan kejelasan terkait variasi pada model regresi yang digunakan. Kekurangannya adalah kurang jelasnya koefisien determinasi dalam penggunaanya terhadap variabel bebas yang digunakan dalam model. Lebih baik nilai Adjust $\mathrm{R}^{2}$ digunakan pada saat ingin mendapatkan model regresi terbaik. Besarnya Adjust $\mathrm{R}^{2}$ adalah 0,785 atau $78,5 \%$. Hal ini berarti bahwa Kepemimpinan Transformasional $\left(X_{1}\right)$ dan Motivasi $\left(\mathrm{X}_{2}\right)$ secara simultan mampu memengaruhi Kinerja $(\mathrm{Y})$ sebesar $78,5 \%$, sedangkan sisanya sebesar $21,5 \%$ merupakan pengaruh dari variabel lain.

Berdasarkan tabel 1 diatas, diketahui $F$ hitung senilai 62,897 . Karena nilai $F$ hitung $62,897>\mathrm{F}$ Tabel 3,28 dimana hasil 3,28 tersebut dapat di cari pada $\mathrm{F}$ tabel sehingga dapat ditarik kesimpulan bahwa hipotesis pertama dapat diterima yang artinya kepemimpinan transformasional $\left(\mathrm{X}_{1}\right)$ dan motivasi $\left(\mathrm{X}_{2}\right)$ secara simultan berpengaruh terhadap kinerja $(\mathrm{Y})$.

Hipotesis penelitian pertama "Ada pengaruh kepemimpinan transformasional dan motivasi terhadap kinerja pengerajin gerabah di Kelurahan Banyuning". Berdasarkan rekapan hasil uji regresi berganda pada Tabel 1 menunjukan hasil $\mathrm{RyX}_{1} \mathrm{X}_{2}=0,893$ dengan p-value $0,00<$ Alpha $(\alpha)$ 0,05, yang menyatakan bahwa menolak Ho yang berarti ada pengaruh positif dan signifikan dari Kepemimpinan Transformasional $\left(\mathrm{X}_{1}\right)$ dan Motivasi $\left(\mathrm{X}_{2}\right)$ terhadap Kinerja (Y), dengan sumbangan pengaruh sebesar 79,7\%. Hasil tersebut menunjukan bahwa sebesar $79,7 \%$ Kinerja (Y) dipengaruhi oleh Kepemimpinan Transformasional $\left(X_{1}\right)$ dan Motivasi $\left(X_{2}\right)$. Sedangkan senilai 20,3\% merupakan pengaruh dari variabel lainnya. Hal ini dapat disimpulkan bahwa variabel Kepemimpinan Transformasional $\left(X_{1}\right)$ dan Motivasi $\left(X_{2}\right)$ secara simultan berperan dalam meningkatkan Kinerja (Y).

Hipotesis penelitian kedua "Ada pengaruh kepemimpinan transformasional terhadap kinerja pengerajin gerabah di Kelurahan Banyuning". Berdasarkan rekapan hasil uji regresi berganda pada Tabel 1 menunjukan hasil $\mathrm{PyX}_{1}=0,463$ dengan $\mathrm{p}$-value 0,006 < Alpha $(\alpha)$ 0,05 hal ini menyatakan bahwa menolak Ho yang berarti ada pengaruh positif dan signifikan dari Kepemimpinan Transformasional $\left(\mathrm{X}_{1}\right)$ terhadap Kinerja $(\mathrm{Y})$, dengan sumbangan pengaruh sebesar $21,4 \%$. Sehingga, dapat disimpukan bahwa variabel Kepemimpinan Transformasional berperan dalam meningkatkan Kinerja.

Hipotesis penelitian ketiga "Ada pengaruh motivasi terhadap kinerja pengerajin gerabah di Kelurahan Banyuning". Berdasarkan rekapan hasil uji regresi berganda pada Tabel 1 menunjukan hasil $\mathrm{PyX}_{2}=0,468$ dengan $\mathrm{p}$-value 0,005 < Alpha $(\alpha) 0,05$ hal ini menyatakan bahwa menolak Ho yang berarti ada pengaruh positif dan signifikan dari Motivasi $\left(\mathrm{X}_{2}\right)$ terhadap Kinerja $(\mathrm{Y})$, dengan sumbangan pengaruh sebesar 21,9\%. Hal ini dapat disimpukan bahwa variabel Motivasi berperan dalam meningkatkan Kinerja.

Variabel bebas yaitu kepemimpinan transformasional dan motivasi berperngaruh signifikan terhadap kinerja pengerajin gerabah di Kelurahan Banyuning. Didorong oleh teori Sedarmayanti (2010:188) dimana dikatakan bahwa kinerja yang meningkat dikarenakan kepemimpinan transformasional dapat meningkatkan motivasi yang berkaitan dengan motivasi sebagai peningkat kinerja pengikutnya. Hal tersebut dikuatkan dengan dengan penelitian Suryani dan Pramandari (2015) kepemimpinan tranformasional dan motivasi berpengaruh positif terhadap kinerja. 
Variabel bebas yaitu kepemimpinan transformasional berpengaruh positif dan signifikan terhadap kinerja pengerajin gerabah di Kelurahan Banyuning. Menurut Munawaroh (2011) Munawaroh (2011) menyatakan bahwa gaya kepemimpinan transformasional membangkitkan motivasi pegawai dalam mencapai kinerja yang lebih dari apa yang diharapkan sebelumnya. Kemudian dikuatkan oleh penelitian Yuliaarnita (2013) yang berkesimpulan bahwa kepemimpinan transformasional secara parsial memiliki pengaruh yang positif dan signifikan terhadap kinerja

Variabel motivasi berpengaruh positif dan signifikan terhadap kinerja pengerajin gerabah di Kelurahan Banyuning. Hal ini didorong oleh teori Griffin (2003) yang mengemukakan bahwa faktor yang sangat mampu menentukan sebuah kinerja adalah motivasi. Motivasi akan mampu meningkatkan semangat karyawan dalam mencapai kinerja. Hal tersebut didorong oleh penelitian Nur dan Sjahruddin (2019) yang berkesimpulan bahwa motivasi secara parsial memiliki pengaruh yang positif dan signifikan terhadap kinerja.

Kepemimpinan Transformasional memiliki pengaruh positif dan signifikan terhadap Kinerja. Kepemimpinan dalam suatu perusahaan ataupun organisasi harus berjalan dengan baik dan selaras. Setiap pegawai maupun atasan harus mengetahui kewajiban, wewenang dan tanggung jawabnya masing-masing agar tercapainya kinerja yang baik dalam suatu perusahaan. Kinerja akan tercapai jika pemimpinnya mampu mengajak bawahan dalam berdiskusi dan pencarian solusi atas permasakah yang terjadi. Pemimpin adalah contoh bagi karyawannya dimana pemimpin harus mampu bersikap bijaksana baik dalam penginformasian perintah maupun dalam bertindak pengambilan keputusan, dari sana lah karyawan akan mengikuti contoh baik pemimpinan dan secara otomatis akan mampu mengingkatkan kinerja perusahaan. Selain itu sebagai atasan harus mampu memberikan motivasi untuk membangkitkan semangat kerja karyawan. Motivasi memberikan pengaruh positif dan signifikan terhadap kinerja. mengartikan motivasi mampu meningkatkan semangat kerja karyawan. Motivasi mampu memberikan dampak dalam meningkatkan kinerja perusahaan. Seseorang yang termotivasi melakukan pekerjaan akan sepenuh hati mengeluarkan tenaga dan pikiran untuk bersama-sama mencapai tujuan yang telah ditetapkan. Motivasi yang diberikan dapat dari keluarga, antar karyawan maupun dari pihak atasan bahkan motivasi akan timbul dari diri sendiri mampu memberikan semangat dalam bekerja. Karena ketika seseorang mendapatkan motivasi dari orang disekitarnya maka orang yang bersangkutan akan lebih semangat dalam menjalani segala hal.

\section{Simpulan dan Saran}

Kesimpulan yang dapat ditarik adalah (1) Kepemimpinan Transformasional dan Motivasi berpengaruh signifikan terhadap Kinerja pengerajin gerabah di Kelurahan Banyuning, (2) Kepemimpinan Transformasional berpengaruh positif dan signifikan terhadap Kinerja pengerajin gerabah di Kelurahan Banyuning, (2) Motivasi berpengaruh positif dan signifikan terhadap Kinerja pengerajin gerabah di Kelurahan Banyuning.

Saran yang dapat penulis berikan sebagai berikut (1) Untuk peneliti selanjutnya diharapkan dapat memberikan tambahan ilmu yang didapat dari penelitian ini dengan mencoba berbagai variabel lai yang dapat mempengaruhi kinerja. Kemudian dikembangkannya lagi subjek penelitian dan dapat memperbanyak teori-teori tentang variabel yang digunakan serta dapat menggunakan teknik analisis data yang lain agar dapat menjadi acuan bagi penelitian-penelitian selanjutnya. Populasi dsn sampel yang diperluas agar penelitian lebih teruji keandalannya dan dapat menambah ilmu pengetahuan khusunya dalam manajemen sumber daya manusia. (2) Bagi UMKM Gerabah Banyuning agar lebih memperhatikan penerapan kepemimpinan transformasional yang harus di tingkatkan dengan gaya pemimpin yang mampu memberikan contoh dan teladan bagi karyawan, mampu mengajak karyawan dalam pemecahan masalah dan pencarian solusi serta dapat membangkitkan semangat karyawan dalam bekerja. Motivasi dapat ditimbulkan dari diri sendiri maupun dari lingkungan luar. Dari dalam diri, pengerajin gerabah meningkatkan semangat dalam bekerja dengan terpenuhinya kebutuhan-kebutuhan seperti gaji dan upah yang sesuai dengan kewajiban yang telah dikerjakan. Sehingga, kepemimpinan transformasional dan motivasi mampu meningkatkan kinerja pengerajin gerabah. Penelitian 
ini memberikan bukti bahwa kepemimpinan trasformasional dan motivasi dapat mempengaruhi kinerja. Tujuannya untuk peningkatan kinerja, meningkatkanya produktifitas, tercapainya target perusahaan, dan pengerajin gerabah di Kelurahan Banyuning yang mampu menyelesaikan pekerjaannya dengan tepat waktu.

\section{Daftar Pustaka}

Arikunto, Suharsimi. 2006. Prosedur Penelitian Suatu Pendekatan Praktik. Jakarta: Rineka Cipta.

Ghozali, Imam. 2009. Aplikasi Analisis Multivariate Dengan Program SPSS. Cetakan Keempat. Semarang: Badan Penerbit Universitas Diponogoro.

Griffin, RW. 2003. Manajemen. Jakarta: Erlangga.

Mangkunegara, Anwar Prabu. 2010. Evaluasi Kinerja Sumber Daya Manusia. Bandung: Refika Aditama.

Munawaroh. 2011. Pengaruh Tunjanhan Kinerja Terhadap Kinerja Pegawai Negeri Sipil Pada Sekolah Tinggi Penyuluhan Pertanian (STPP) Gowa. Jurnal IImiah Aksi STIE AMKOP Makassar. Volume 4, Nomor 1

Nur, I.G, dkk. 2019. "Pengaruh Kepemimpinan Transformasional dan Motivasi Kerja Terhadap Kinerja Pegawai". Jurnal Organisasi dan Manajemen, Volume 1 (hlm.47$57)$.

O'Leary, Elizabeth. 2001. Kepemimpinan. Edisi Pertama. Yogyakarta: Andi.

Rivai, Veithzal. 2005. Performance Appraisal. Jakarta: PT. Raja Grafindo Persada.

Sedarmayanti. 2010. Sumber Daya Manusia dan Produktifitas Kerja. Mandar Maju:Bandung.

Muchdarsyah, Sinungan. 2003. Produktifitas: Apa dan Bagaimana. Bandung: Mandar Maju.

Sugiyono. 2009. Metode Penelitian Bisnis (Pendekatan Kuantitatif, Kualitatif dan R\&D). Bandung: CV Alfabeta.

Sunyoto, Danang. 2012. Teori, Kuisioner, dan Analisis Data Sumber Daya Manusia. Yogyakarta: CAPS (Center for Academic Publishing Service).

Suryani, N., dkk. 2015. "Pengaruh Kepemimpinan Transformasional dan Motivasi terhadap Kinerja Karyawan”. JUIMA: Jurnal IImu Manajemen, Volume 6, Nomor 2.

Umar, Husein. 2004. Riset Sumber Daya Manusia dalam Organisasi.Jakarta: Gramedia Pustaka Utama.

Yukl, Gary. 2009. Kepemimpinan dalam Organisasi. Jakarta: Indeks.

Yuliaarnita, Komang A. 2013. "Pengaruh Gaya Kepemimpinan Transformasional dan Motivasi Terhadap Kinerja Karyawan pada PT. Sorga Indah Handicrafts". Jurnal Telkom University, Volume 1 (hlm.1-11). 